\title{
KONVERSI IKAN ASIN MENJADI NUGGET BERSERAT PANGAN DENGAN TAMBAHAN AMPAS TAHU DAN BEBERAPA JENIS BINDER
}

\author{
Hardoko*, Bambang Budi Sasmito, Yunita Eka Puspitasari, Nyimas Lilyani \\ Proram Studi Teknologi Hasil Perikanan, Jurusan Manajemen Sumberdaya Perikanan, Fakultas Perikanan \\ dan Ilmu Kelautan, Universitas Brawijaya. JalanVeteran No. 1 Malang 65113 Jawa Timur \\ Telepon /Faks. 0341- 553512 \\ *Korespodensi: hardoko@ub.ac.id \\ Diterima: 21 Juni 2016/ Disetujui: 27 Maret 2018
}

Cara sitasi: Hardoko, Sasmito BB, Puspitasari YE, Lilyani N. 2018. Konversi ikan asin menjadi nugget berserat pangan dengan tambahan ampas tahu dan beberapa jenis binder. Jurnal Pengolahan Hasil Perikanan Indonesia. 21(1): 54-67.

\begin{abstract}
Abstrak
Ikan asin merupakan produk tradisional yang tingkat konsumsi dan popularitasnya menurun, sehingga perlu dikembangkan menjadi produk pangan fungsional dengan memanfaatkan sumber serat yang kurang termanfaatkan. Penelitian ini bertujuan untuk menentukan jenis dan konsentrasi bahan pengikat pada pembuatan nugget ikan asin berserat pangan dengan memanfaatkan ampas tahu. Penelitian menggunakan rancangan acak lengkap faktorial (RALF) dengan faktor pertama adalah perbedaan jenis tepung sebagai binder (tepung maizena, tepung tapioka dan tepung terigu) dan faktor kedua adalah konsentrasi tepung $(10 \%, 20 \%, 30 \%)$ terhadap berat daging ikan dan ampas tahu. Hasil penelitian menunjukkan bahwa jenis tepung tidak berpengaruh terhadap karakteristik fisik dan organoleptik nugget, tetapi interaksi antara jenis dan konsentrasi tepung berpengaruh pada rendemen, tekstur, kadar air dan tingkat kesukaan nugget ikan asin. Tepung maizena, tepung tapioka maupun tepung terigu dapat digunakan sebagai bahan pengikat nugget. Nugget ikan asin terpilih adalah nugget dengan bahan pengikat tepung tapioka konsentrasi $30 \%$ dengan nilai tekstur 14,30 Newton (secara organoleptik agak empuk), kadar air 27,48\%, kadar protein 6,88\%, kadar lemak 5,84\%, kadar abu 2,31\%, dan serat pangan 9,30\%. Karakteristik organoleptik nugget agak berasa asin dengan aroma ikan asin dan secara keseluruhan disukai panelis.
\end{abstract}

Kata kunci : ampas tahu, ikan asin, nugget, serat, tepung

\section{Salted Fish Conversion to Fish Nugget Enriched with Dietary Fiber from Okara and Several Binders}

\begin{abstract}
Salted fish is a traditional product that levels of consumption and its popularity continues to decline, so it needs to develop into functional food products by utilizing underutilized source of fiber. The purpose of this study was to determine the type and concentration of binders in the making of salted fish nugget that contained fibre by utilizing the okara. The method used was experimental treatment including types of flour as a binder (cornstarch, tapioca starch, and wheat flour) and the concentration of flour (10\%, 20\%, $30 \%$ of the weight of fish flesh and okara, where the ratio of meat salted fish to okara 1:1). The results showed that the type of flour did not affect the physical characteristics and organoleptic of nugget, but the concentration of flour and interaction of the treatments affected on yield, texture, moisture content, and the level of preference of nugget salted fish. Cornstarch, tapioca flour and wheat flour can be used as a binder in nugget formulation, but the selected salted fish nugget was made using tapioca starch at a concentration of $30 \%$. the characteristics of salted fish nugget were texture of 14.30 Newton (soft), moisture of $27.48 \%$, protein content of $688 \%$, fat content $5.84 \%$, ash content of $2.31 \%, 9.30 \%$ dietary fiber. The organoleptic characteristics of the nugget were slightly salty with salted fish aroma, and overall the panelists preferred.
\end{abstract}

Keywords: fiber, flour, nugget, okara, salted fish 


\section{PENDAHULUAN}

Ikan asin merupakan produk tertua hasil pengolahan ikan yang sangat popular di berbagai negara termasuk Indonesia(Ali 2012). Menurut Widayanti dan Laksmita (2017) sekitar 50\% hasil perikanan di Indonesia diolah menjadi ikan asin. Metode yang digunakan untuk memproduksi ikan asin dapat dilakukan dengan penggaraman kering atau penggaraman basah (Ünlüsayın et al. 2008; Ünlüsayın et al. 2011; Barat et al. 2002; Barat et al. 2003). Jumlah garam yang digunakan dalam penggaraman bervariasi dari 15-30\% (w/w) (Barat et al. 2002; Witono et al. 2013; Nguyen et al. 2010), sehingga kadar garam produk ikan asin juga bervariasi. Salosa (2013) melaporkan kadar garam ikan tenggiri asin di Papua Barat 9,73-16,31 \%, sedangkan Syahruddin (2013) melaporkan kadar garam ikan layang asin yaitu berkisar 1,26-39,09\%. Kadar garam yang tinggi mengakibatkan ikan asin menjadi terasa sangat asin, agak keras, dan mempunyai rasa dan aroma spesifik yang kuat.

Masalah atau dampak negatif yang muncul dari kondisi ikan asin tersebut di Indonesia adalah ikan asin tidak dapat dikonsumsi oleh semua tingkatan umur karena sangat asin (berkadar garam tinggi), relatif keras, umumnya berduri, bahkan saat ini tidak semua lapisan masyarakat Indonesia mau mengkonsumsi ikan asin dan adanya hubungan antara garam dengan tekanan darah dan status sosial. Gilbert and Heiser (2005) menyatakan bahwa ada hubungan antara garam dengan tekanan darah. He dan MacGregor (2008) melaporkan bahwa tinginya kadar garam pada ikan asin secara nyata mempengaruhi tekanan darah dan terjadi pembengkakan pada hampir seluruh organ dalam tubuh, serta meningkatkan jumlah kehilangan mineral tubuh melalui ekskresi urin pada tikus percobaan.

Alternatifyang ditawarkan adalah mengatur dan mengurangi kadar garam sebelum dikonsumsi sekaligus mendiversifikasikan ikan asin menjadi produk pangan fungsional yang bermanfaat untuk kesehatan (Barat et al. 2004). Pengurangan kadar garam sebelum dikonsumsi dapat dilakukan dengan perendaman ikan asin dalam air atau dengan menambahkan bahan pengisi (filler) sehingga proporsi garam dalam produk akan menurun.

Produk yang berpotensi dapat mengatasi masalah ikan asin salah satunya adalah nugget. Pertimbangannya adalah nugget dapat dibuat dari bermacam-macam bahan, ditambahkan bahan pengisi, dan dapat menggunakan bermacam-macam bahan pengikat (binder). Nugget ikan juga mempunyai keunggulan yakni sehat dan bergizi, empuk, rasa bisa bervariasi, dan hampir semua tingkatan umur bisa mengkonsumsi, bisa dijual di pasar tradisional dan pasar modern. Fleksibilitas atau variasi dari produk nugget misalnya, nugget ikan patin dengan filler tepung kanji (Desmelati dan Hayati 2008), nugget ayam dengan filler tepung umbiumbian (Kusumaningrum et al. 2013), nugget ayam dengan filler jamur tiram (Laksono et al. 2012), nugget ayam dengan filler kacang hijau (Nurhalimah et al. 2012), nugget ikan toman dengan bahan pengikat tapioka (Restu 2012), nugget ayam dengan filler rumput laut (Rosyidi et al. 2008) dan nugget singkong (Saniah dan Rohani 2011), nugget ayam dengan penyalut tepung sagu (Yusop et al. 2009).

Produk pangan fungsional adalah produk pangan yang mempunyai fungsi untuk kesehatan. Menurut Marsono (2008) produk pangan fungsional yang mempunyai prospek tinggi diantaranya adalah produk berserat pangan. Pengembangan produk fungsional perikanan juga telah dilakukan, misalnya memanfaatkan rumput laut sebagai sumber serat pangan di antaranya cake rumput laut (Handayani dan Aminah 2011),cookies berserat tinggi dari rumput laut (Riyanto dan Wilakstanti 2006), Produk nuget ikan asin juga dapat ditingkatkan menjadi produk fungsional dengan menambahkan bahan lain yang bersifat fungsional misalnya ampas tahu yang berserat pangan tinggi dan komponen gizi lain. Redondo-Cuenca et al. (2008) melaporkan bahwa ampas tahu memiliki kandungan serat tidak larut air 50,77\%, serat larut air $4,71 \%$, protein $28,52 \%$, lemak $9,84 \%$, abu $3,61 \%$ dan karbohidrat 2,56\% (bk). Ampas tahu dapat berfungsi untuk kesehatan dan 
dapat pula berfungsi sebagai bahan pengisi (filler) yang dapat meningkatkan volume nuget. Nugget juga dapat dibuat fungsional dengan menambahkan asam lemak esensial dari minyak ikan hasil samping pengalengan (Estiasih et al. 2017).

Serat pangan dapat berfungsi untuk kesehatan (Kusharto 2006). Fairudz dan Nisa (2015) menyatakan bahwa serat pangan mempunyai manfaat untuk kesehatan, meliputi melancarkan pencernaan dan mencegah kanker kolon, menurunkan kadar glukosa darah, berfungsi sebagai prebiotik, mengontrol kegemukan dan obesitas serta mengurangi kadar kolesterol dalam darah. Astawan et al. (2005) menyatakan bahwa serat pangan dari rumput laut yang didominasi serat pangan larut air juga mampu menurunkan kolesterol darah tikus hiperglikemia. Serat pangan larut air lebih cepat menurunkan kolesterol dari pada serat pangan tidak larut air. Chandalia et al. (2006) menyatakan bahwa konsumsi serat pangan (dietary fibre) yang direkomendasikan adalah serat larut air karena meningkatkan kontrol terhadap gula darah, menurunkan hiperinsulinemia dan menurunkan konsentrasi plasma lipid pasien diabetes tipe 2 .

Penelitian pengembangan produk ikan asin menjadi produk nugget, khususnya nugget fungsional dengan memanfaatkan ampas tahu belum pernah dilaporkan. Ampas tahu dimanfaatkan sebagai filler, sumber tambahan protein dan sekaligus sumber serat pangan yang berguna bagi kesehatan. Daging ikan asin dan ampas tahu tidak mempunyai kemampuan daya ikat yang baik untuk produk nugget, maka dibutuhkan bahan pengikat untuk menyatukan kedua bahan sehingga menghasilkan tekstur nugget yang baik. Penelitian yang dilakukan bertujuan untuk menentukan jenis dan konsentrasi bahan pengikat pada pembuatan nugget ikan asin berserat pangan dengan memanfaatkan ampas tahu.

\section{BAHAN DAN METODE Bahan dan Alat}

Bahan utama yang digunakan dalam penelitian ini adalah ikan asin dari ikan kembung (Rastrelliger kanagurta) yang didapat dari pasar tradisional Merjosari, Malang dengan spesifikasi bentuknya utuh, tidak berbau asam atau tengik, tidak terdapat bercak noda dan tidak lembek berair. Ampas tahu yang diperoleh dari industri pengolahan tahu Karangploso, Malang dengan spesifikasi tidak berbau asam atau busuk dan bersih. Bahan pengikat yang digunakan adalah tepung maizena (Maizenaku), tepung tapioka (Rose Brand), tepung terigu (segitiga biru). Bumbu-bumbu yang digunakan meliputi bawang putih, gula, garam, telur, susu skim, air es, merica, ketumbar. Bahan battering diantaranya yaitu tepung tapioka, merica, telur ayam, air. Bahan breading yaitu panir. Bahanbahan kimia yang diperlukan untuk analisis proksimat yaitu silika gel, $\mathrm{K}_{2} \mathrm{~S}_{2} \mathrm{O} 4$ (Merck), $\mathrm{H}_{2} \mathrm{SO}_{4}$ (Merck), $\mathrm{K}_{2} \mathrm{~S}$ (Merck), $\mathrm{NaOH}$ (Merck), $\mathrm{HCl}$ (Merck), $\mathrm{AgNO}_{3}$ (Merck), $\mathrm{KCl}$ (Merck), $\mathrm{K}_{2} \mathrm{CrO}_{4}$ (Merck), $\mathrm{HgO}$ (Merck), petroleum eter (Merck), $\mathrm{CH}_{3} \mathrm{COOH}$ (Merck), akuades, etanol(Merck), aseton (Merck), kertas saring dan antifoam.

Alat yang dibutuhkan pada pembuatan nugget adalah chopper, wajan penggorengan, dandang pengukus, loyang dan freezer. Peralatan untuk analisis proksimat adalah timbangan analitik (Nettler Toledo AB204-S), oven (merk Memmert), soxhlet, labu destilasi, tabung destruksi, peralatan gelas (Iwaki Pyrex), buret dan statif, botol timbang, tungku pengabuan (Merk Memmert)dan hot plate (Memmert).

\section{Metode Penelitian}

Metode penelitian yang digunakan adalah metode eksperimen dengan perlakuan penambahan jenis tepung bahan pengikat (binder) dan konsentrasi bahan pengikat pada pembuatan nugget ikan asin. Jenis tepung bahan pengikat yang digunakan adalah tepung maizena $(\mathrm{M})$, tepung tapioka $(\mathrm{T})$ dan tepung terigu $(G)$, dengan konsentrasi masing-masing tepung adalah $10 \%, 20 \%$, dan $30 \%$ terhadap berat daging ikan dan ampas tahu. Daging ikan asin dan ampas tahu yang digunakan dengan rasio 1:1. Perlakuan ini diformulasikan pada Tabel 1. 


\section{Pembuatan nugget ikan asin}

Pembuatan nugget ikan asin didasarkan pada metode Lutfi (2011) yang dimodifikasi. Pembuatan nugget ikan asin diawali dengan penanganan ampas tahu yang dilakukan dengan pemerasan dengan kain blacu, pengukusan selama 30 menit, pengeringan dengan sinar matahari, sehingga diperoleh ampas tahu kering. Ikan asin direndam dalam air panas selama 30 menit, dagingnya diambil dan dihaluskan dengan chopper sehingga diperoleh daging ikan asin lumat. Penanganan bumbu-bumbu yaitu dibersihkan dan dihaluskan dengan chopper, sehingga diperoleh bumbu halus. Ampas tahu, lumatan daging ikan asin, bumbu halus telur, susu skim, tepung (maizena, tapioka dan terigu) dan air es dicampur sesuai konsentrasi menggunakan mixer. Adonan yang diperoleh selanjutnya dicetak dalam loyang dan dikukus sampai matang, setelah dingin diiris (dicetak). Adonan penyalut (batter) disiapkan dengan mencampurkan tepung tapioka dan telur sampai merata dan kental. irisan nugget dicelupkan dalam adonan batter dan diguling-gulingkan pada tepung roti atau panir dan dilanjutkan dengan penggorengan setengah matang (prefrying), pendinginan, pengemasan dan penyimpanan beku.

\section{Analisis tekstur dengan penetrometer}

Analisis tekstur dengan menggunakan penetrometer mengacu pada Suwanto et al. (2012). Sampel disiapkan dengan ukuran dan ketebalan yang sama, serta ditentukan satu titik yang sama untuk ditekan dengan jarum penetrometer, sehingga terjadi perubahan jarak tekan. Hasil dibaca pada angka yang ditunjuk pada alat penetrometer.

\section{Analisis kadar air}

Analisis kadar air mengacu pada metode AOAC (2005). Botol timbang dibersihkan dan dikeringkan pada oven bersuhu $105^{\circ} \mathrm{C}$ selama semalam dengan tutup setengah terbuka. Botol timbang yang sudah kering dimasukkan dalam desikator selama 15-30 menit dan ditimbang beratnya. Sampel ditimbang (sekitar 2 gram) dan dimasukkan dalam botol timbang. Botol timbang berisi sampel

Kadar air $(\% \mathrm{bb})=\frac{(\text { berat botol timbang+sampel })-(\text { berat akhir })}{\text { berat sampel awal }} \times 100 \%$

Tabel 1 Formulasi nugget ikan asin-ampas tahu berdasarkan jenis dan konsentrasi tepung yang digunakan (dalam \% terhadap berat daging ikan)

(Table 1 Formulation of nuggets made from salted fish-okara based on the type and concentration of flour used (in \% to the weight of fish meat))

\begin{tabular}{cccccccccc}
\hline \multirow{2}{*}{ Formulasi/Formulation } & \multicolumn{10}{c}{ Perlakuan/Treatament } \\
\cline { 2 - 10 } & $\mathrm{M}_{10}$ & $\mathrm{M}_{20}$ & $\mathrm{M}_{30}$ & $\mathrm{~T}_{10}$ & $\mathrm{~T}_{20}$ & $\mathrm{~T}_{30}$ & $\mathrm{G}_{10}$ & $\mathrm{G}_{20}$ & $\mathrm{G}_{30}$ \\
\hline Daging ikan asin/Salted fish meat $(\mathrm{g})$ & 100 & 100 & 100 & 100 & 100 & 100 & 100 & 100 & 100 \\
Okara (g) & 100 & 100 & 100 & 100 & 100 & 100 & 100 & 100 & 100 \\
Tepung maizena/Cornstarch (g) & 20 & 40 & 60 & - & - & - & - & - & - \\
Tepung tapioka/Tapioca flour (g) & - & - & - & 20 & 40 & 60 & & - & - \\
Tepung terigu/Wheat fllour (g) & - & - & - & - & - & - & 20 & 40 & 60 \\
Bawang putih/Garlic (g) & 4 & 4 & 4 & 4 & 4 & 4 & 4 & 4 & 4 \\
Ketumbar/Coriander (g) & 2 & 2 & 2 & 2 & 2 & 2 & 2 & 2 & 2 \\
Gula/Sugar (g) & 3 & 3 & 3 & 3 & 3 & 3 & 3 & 3 & 3 \\
Lada/Pepper (g) & 2 & 2 & 2 & 2 & 2 & 2 & 2 & 2 & 2 \\
Susu skim/Skim milk (g) & 7 & 7 & 7 & 7 & 7 & 7 & 7 & 7 & 7 \\
Telur/Egg (items) & 2 & 2 & 2 & 2 & 2 & 2 & 2 & 2 & 2 \\
Air es/Ice water (g) & 20 & 20 & 20 & 20 & 20 & 20 & 20 & 20 & 20 \\
\hline
\end{tabular}


dimasukkan dalam oven bersuhu $105^{\circ} \mathrm{C}$ dan setiap 2 jam ditimbang sampai beratnya konstan (berat akhir).

\section{Analisis kadar serat pangan (AOAC 2005)}

Analisis kadar serat pangan mengacu pada metode AOAC (2005). Sampel ditimbang sejumlah 1 gram dan dimasukkan dalam gelas beaker, ditambahkan $50 \mathrm{~mL} \mathrm{0,1}$ $\mathrm{M}$ buffer natrium fosfat $\mathrm{pH} 6$ dan $0,1 \mathrm{~mL}$ enzim termamyl, campuran diinkubasi dalam waterbath pada suhu $1000 \mathrm{C}$ selama 15 menit dan digoyangkan setiap 5 menit, ditambah $10 \mathrm{~mL}$ larutan $0,275 \mathrm{~N} \mathrm{NaOH}$ hingga $\mathrm{pH}$ menjadi 7,5, ditambahkan 5 gram protease dan 0,1 mL larutan enzim dilanjutkan dengan inkubasi selama 30 menit. Hasil inkubasi ditambahkan $10 \mathrm{~mL}$ larutan $\mathrm{HCl}$ dan diatur $\mathrm{pH}$ hingga 4,0-4,6, terus ditambahkan 0,3 ml amyloglukosidase, ditutup aluminium foil dan diinkubasi kembali pada suhu $60^{\circ} \mathrm{C}$ selama 30 menit. Hasil inkubasi disaring dengan krus yang diberi celite $0,1 \mathrm{mg}$ dan diratakan dengan etanol $78 \%$. Residu yang diperoleh dalam krus dicuci dengan $20 \mathrm{ml}$ etanol 78\%

Serat larut $(g / 100 g)=\frac{(C-B)-(E-D) \text { blanko }}{A} \times 100 \%$

Serat tidak larut $=\frac{(C-B)-(E-D) \text { blanko }}{A} \times 100 \%$

Keterangan:

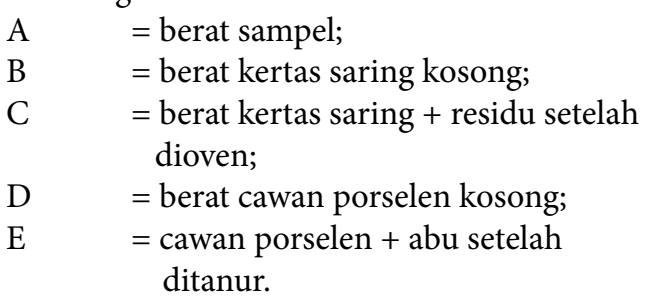

(3x), $10 \mathrm{~mL}$ etanol 95\% (2x) dan $10 \mathrm{ml}$ aseton (1x), kemudian residu dikeringkan dalam oven vakum $70 \%$ selama semalam atau dioven $105^{\circ} \mathrm{C}$ sampai berat konstan.

\section{Analisis Organoleptik}

Analisis organoleptik produk nugget mengacu pada metode Meilgaard et al. (1999). Uji organoleptik hedonik yang dilakukan pada produk nugget ikan asin meliputi tingkat kesukaan terhadap rasa asin, aroma ikan asin, tekstur, penerimaan secara keseluruhan. Skor tingkat kesukaan yang digunakan adalah 1-7, dimana 1 = sangat tidak suka, $2=$ tidak suka, $3=$ cukup suka, $4=$ suka, $5=$ lebih suka, $6=$ sangat suka, 7 = amat sangat suka.

Uji organoleptik skoring digunakan untuk menguji karakter nugget ikan asin berupa rasa asin, aroma ikan asin dan tekstur. Skor rasa asin yang digunakan adalah $1=$ sangat tidak asin, $2=$ tidak asin, $3=$ agak asin, $4=$ asin, $5=$ agak lebih asin, $6=$ sangat asin, $7=$ amat sangat asin. Skor aroma ikan asin yang digunakan adalah $1=$ sangat tidak terasa; $2=$ tidak terasa; $3=$ agak terasa; $4=$ terasa; $5=$ agak lebih terasa; $6=$ sangat terasa; $7=$ amat sangat terasa. Skor tekstur yang digunakan adalah $1=$ sangat tidak empuk; $2=$ tidak empuk; $3=$ agak empuk; $4=$ empuk; $5=$ agak lebih empuk; 6= sangat empuk; $7=$ amat sangat empuk.

\section{Analisis Data}

Data dianalisis berdasarkan menggunakan program komputer SPSS 16 . Rancangan penelitian menggunakan rancangan acak lengkap (RAL) faktorial dengan 3 kali ulangan.

\section{HASIL DAN PEMBAHASAN Karakteristik Gizi Bahan Baku Nugget Ikan Asin}

Karakteristik gizi bahan berdasarkan komposisi kimia, serat pangan, dan kadar garam dapat dilihat pada Tabel 2. Karakteristik yang dibutuhkan untuk pembuatan nugget ikan asin khususnya adalah kadar garam dari ikan asin dan kadar serat pangan dari ampas tahu. Hal ini terkait dengan produk nugget yang diharapkan adalah tidak asin, berserat pangan, dan tetap beraroma ikan asin.

Persyaratan mutu ikan asin kering (BSN 1992) terdiri dari kadar air maksimal $40 \%$, dan kadar garam maksimum 20\%. Ikan kembung asin yang digunakan sebagai bahan baku nugget ikan asin tidak memenuhi syarat kadar airnamun kadar garamnya memenuhi persyaratan. Kadar garam yang cukup tinggi pada ikan kembung asin mengakibatkan ikan asin menjadi awet, bila dikombinasikan dengan kadar air maka menghasilkan ikan asin yang tidak terlalu kering, awet dan cukup asin, kondisi ikan asin ini mengakibatkan daging ikan asin tidak terlalu keras (liat) sehingga 
Tabel 2 Komposisi gizi bahan baku nugget ikan asin (Table 2 Nutritional composition of raw material salted fish nuggets)

\begin{tabular}{ccccc}
\hline & \multicolumn{2}{c}{ Salted fish } & \multicolumn{2}{c}{ Okara } \\
\cline { 2 - 5 } Component & Content & Ira (2008) & Content & $\begin{array}{c}\text { Sulistiani } \\
(2004)\end{array}$ \\
\hline Kadar air/Moisture (\%) & 45.58 & 43.85 & 82.00 & 89.88 \\
Kadar protein/Protein (\%) & 31.91 & 28.44 & 3.14 & 2.20 \\
Kadar lemak/Lipids (\%) & 0.64 & 4.73 & 0.85 & 0.32 \\
Kadar abu/Ash (\%) & 17.48 & 11.92 & 0.49 & 1.32 \\
Karbohidrat/Carbohydrate (\%) & 4.39 & - & 11.27 & 6.33 \\
Kadar serat/Food fiber (\%) & - & - & 6.72 & 5.69 \\
Kadar garam/Salt (\%) & 12.47 & - & - & - \\
\hline
\end{tabular}

lebih mudah diambil dagingnya untuk dijadikan bahan nugget. Kadar garam yang cukup tinggi pada ikan asin (12,47\%) perlu dikurangi agar nugget yang dihasilkan tidak terlalu asin. Pengurangan kadar garam dapat dilakukan dengan perendaman bahan baku awal dengan air atau menambahkan bahan pengisi di antaranya ampas tahu sehingga dapat menjadi produk olahan berupa nugget.

Ampas tahu yang digunakan memiliki karakteristik yang cenderung lebih baik jika dibandingkan dengan ampas tahu yang digunakan pada penelitian Sulistiani (2004), khususnya kadar protein dan serat pangan. Berdasarkan karakteristik ampas tahu tersebut maka ampas tahu dapat dijadikan sebagai bahan pengisi nugget sekaligus sebagai sumber serat pangan nugget ikan. Kadar air dalam ampas tahu cukup tinggi dapat sehingga mengakibatkan cepat busuk, maka perlu segera diberi perlakuan pemanasan atau pengeringan (Suprapti 2005).

Karakteristik fisik daging ikan asin dan juga ampas tahu yang tidak mempunyai daya rekat, maka perlu ditambahkan jenis dan jumlah bahan pengikat yang sesuai dalam pembuatan nugget ikan asin.

\section{Karakteristik Nugget Berdasarkan Jenis dan Konsentrasi Binder Rendemen nugget}

Rendemen digunakan untuk menghitung hasil yang diperoleh dari bahan-bahan yang digunakan, sehingga dapat digunakan untuk efisiensi proses dan harga jual produk (Miwada dan Simpen 2014). Hasil uji lanjut dengan Tukey menunjukkan bahwa konsentrasi tepung yang digunakan dan interaksi antara jenis tepung dan konsentrasi tepung yang digunakan berpengaruh nyata terhadap rendemen nugget $(p<0,05)$. Hasil rendemen nugget dapat dilihat pada Gambar 1.

Hasil uji lanjut Tukey menunjukan bahwa rendemen nugget perlakuan konsentrasi tepung $30 \%$ berbeda nyata dengan perlakuan konsentrasi tepung $10 \%$ namun tidak berbeda nyata dengan konsentrasi tepung 20\% $(p<0,05)$. Perbedaan ini terkait dengan kadar dan komposisi pati sebagai bahan pengikat yang digunakan. Rendemen dipengaruhi oleh kadar pati dalam tepung yang digunakan Anggraeni et al. (2014). Granula pati dapat mengembang jika menyerap air, apabila pati yang sudah menyerap air dipanaskan, maka energi panas dapat memecah ikatan hidrogen sehingga kemampuan pati dalam mengikat air semakin meningkat dan mengakibatkan pati dapat mengembang lebih besar. Jumlah pati dan jumlah air yang terserap akan mempengaruhi rendemen produk. Berdasarkan hasil uji lanjut rendemen nugget dapat dinyatakan bahwa rendemen tertinggi adalah pada penambahan tepung pengikat $30 \%$.

\section{Tekstur nugget}

Nilai tekstur dalam satuan newton menunjukan semakin besar nilai yang dihasilkan maka semakin keras tekstur produk. Hasil uji lanjut Tukey menunjukkan bahwa konsentrasi tepung, serta interaksi 


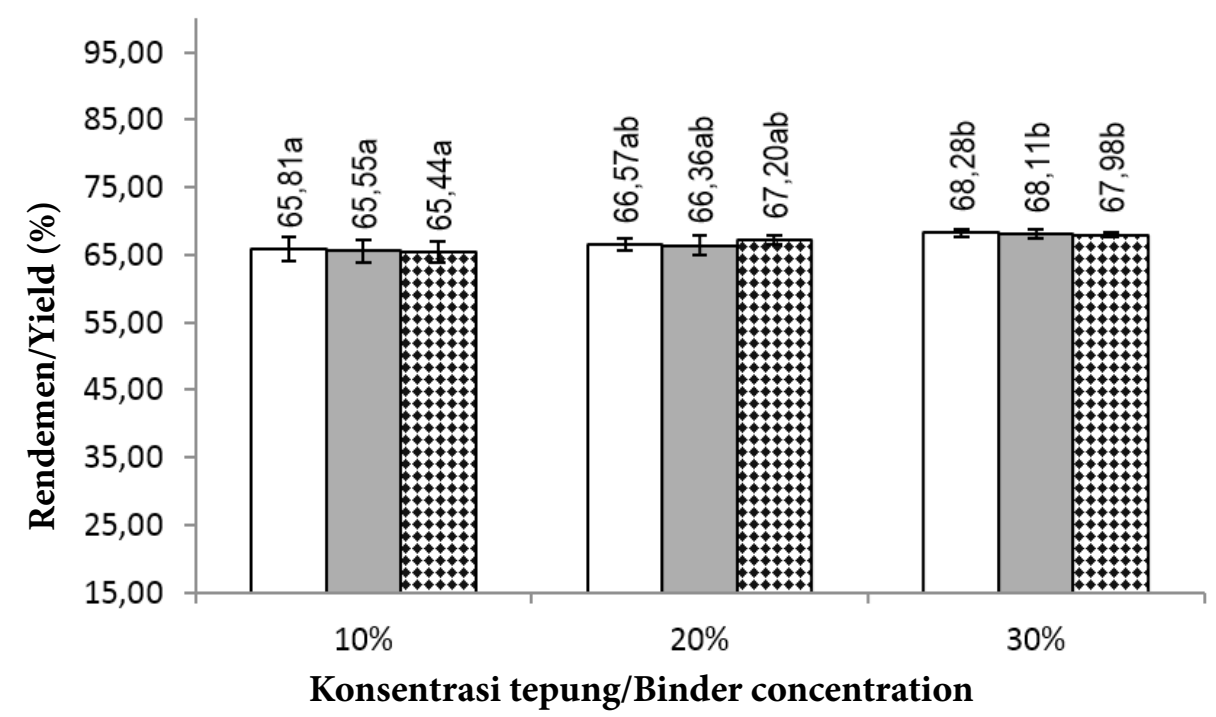

Gambar 1 Rendemen nugget ikan asin dengan berbagai jenis dan konsentrasi tepung binder.

$\square$ : maizena; $\square$ : tapioka; $\square$ : terigu.

(Figure 1 Yield of salted fish nugget with various types and concentration of binder flour.

$\square$ : cornstarch; $\square$ : tapioca; $\mathbb{Q}$ : wheat.)

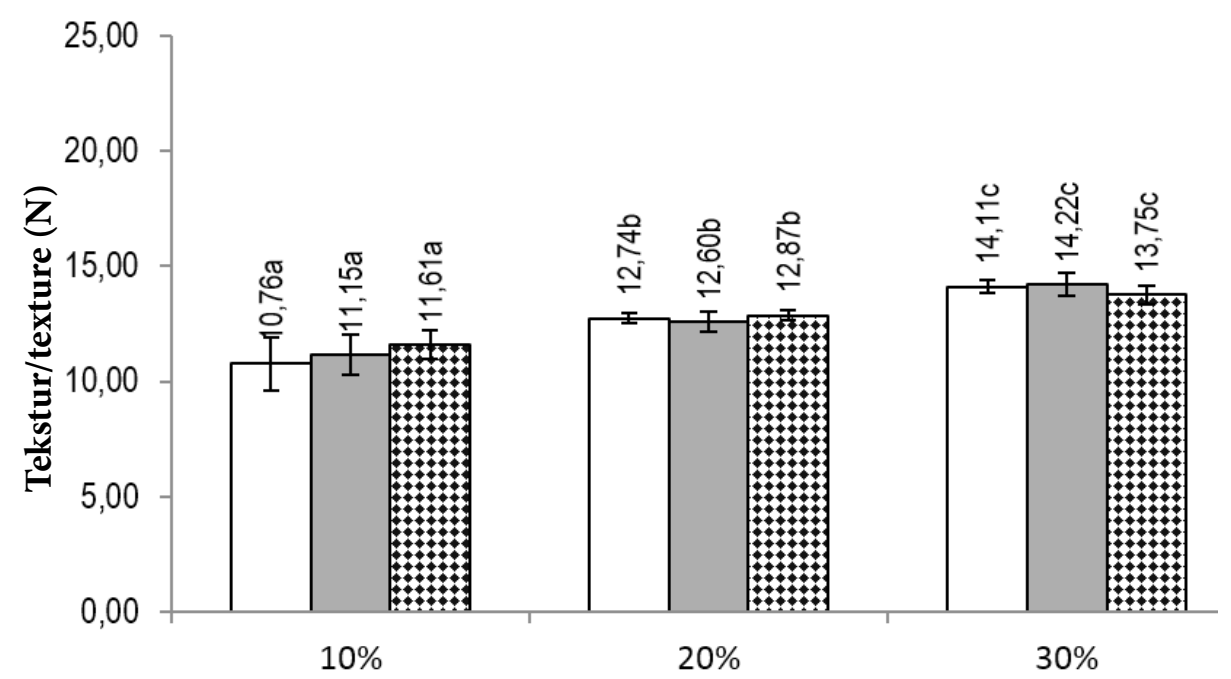

Konsentrasi tepung/binder concentration

Gambar 2 Tekstur nugget ikan asin berdasar jenis dan konsentrasi binder. $\square$ :maizena;

$\square$ : tapioka; $\square$ : terigu. Notasi huruf beda dibelakang angka menunjukkan beda nyata $(\mathrm{p}<0,05)$.

(Figure 2 Texture of salted fish nugget with various types and concentration of binder flour.

$\square$ : cornstarch; $\square$ : tapioca; $\square$ : wheat. Different letter notations behind the numbers show significantly different $(p<0.05))$.

antara konsentrasi tepung dan jenis tepung yang digunakan berpengaruh nyata terhadap tekstur atau kekerasan nugget $(p<0,05)$. Hasil tekstur naget dapat dilihat pada Gambar 2.

Gambar 2 menunjukkan nilai tekstur nugget yang ditambah tepung konsentrasi $30 \%$ berbeda nyata dengan yang ditambah tepung $10 \%$ dan $20 \%(\mathrm{p}<0,05)$. Peningkatan ini diduga terkait dengan adanya interaksi antara gelatinisasi pati dengan bahan 
nugget yaitu ikan asin dan ampas tahu yang akan membentuk tekstur tertentu. Surawan (2007) menyatakan bahwa penambahan pati yang banyak dapat membuat tekstur lebih padat dan keras, serta tesktur akan berubah dengan berubahnya kandungan air, sedangkan Zulkarnain (2013) menjelaskan bahwa pati memegang peranan penting dalam menentukan tekstur makanan, apabila campuran granula pati dan air dipanaskan akan membentuk gel. Pati yang berubah menjadi gel bersifat irreversible, molekulmolekul pati saling melekat membentuk suatu gumpalan sehingga membentuk tekstur. Aristawati (2013) dan Muklas (2010) menyatakan bahwa semakin banyak tepung terigu yang digunakan, maka teksturnya akan semakin kenyal, hal tersebut terkait dengan interaksi protein gluten dan gelatinisasi pati terigu. Penambahan tepung tapioka yang semakin banyak juga dapat menyebabkan produk lebih padat karena tepung tapioka memiliki amilopektin tinggi yang mampu menyerap air lebih banyak. Menurut Belitz et al. (2009), kondisi ini dapat terjadi karena jumlah gugus hidroksil pada molekul pati sangat besar sehingga kemampuan menyerap air menjadi besar pula.
Berdasarkan Gambar 2 dapat dinyatakan bahwa tekstur atau kekerasan nugget lebih dipengaruhi konsentrasi tepung bahan pengikat yang digunakan. Nugget yang ditambah tepung bahan pengikat $10 \%$ dapat dikatakan lebih empuk daripada yang ditambah tepung bahan pengikat $20 \%$ dan $30 \%$, meskipun tekstur merupakan parameter penting pada nugget, namun tetap diperlukan parameter lain seperti organoleptik untuk menentukan pemilihan nugget terbaik. Parameter organoleptik hedonik dapat membantu mengetahui tekstur yang disukai oleh panelis.

\section{Kadar air nugget}

Hasil uji lanjut Tukey menunjukkan bahwa konsentrasi tepung yang digunakan dan interaksi antara konsentrasi dan jenis tepung berpengaruh nyata terhadap kadar air nugget ikan asin $(\mathrm{p}<0,05)$. Hasil uji lanjut terhadap kadar air dapat dilihat pada Gambar 3.

Gambar 3 menunjukkan bahwa kadar air pada nugget yang ditambah tepung $10 \%$ berbeda nyata daripada yang ditambah tepung $20 \%$ dan $30 \% \quad(\mathrm{p}<0,05)$. Terjadi perubahan kadar air nugget ikan asin dengan

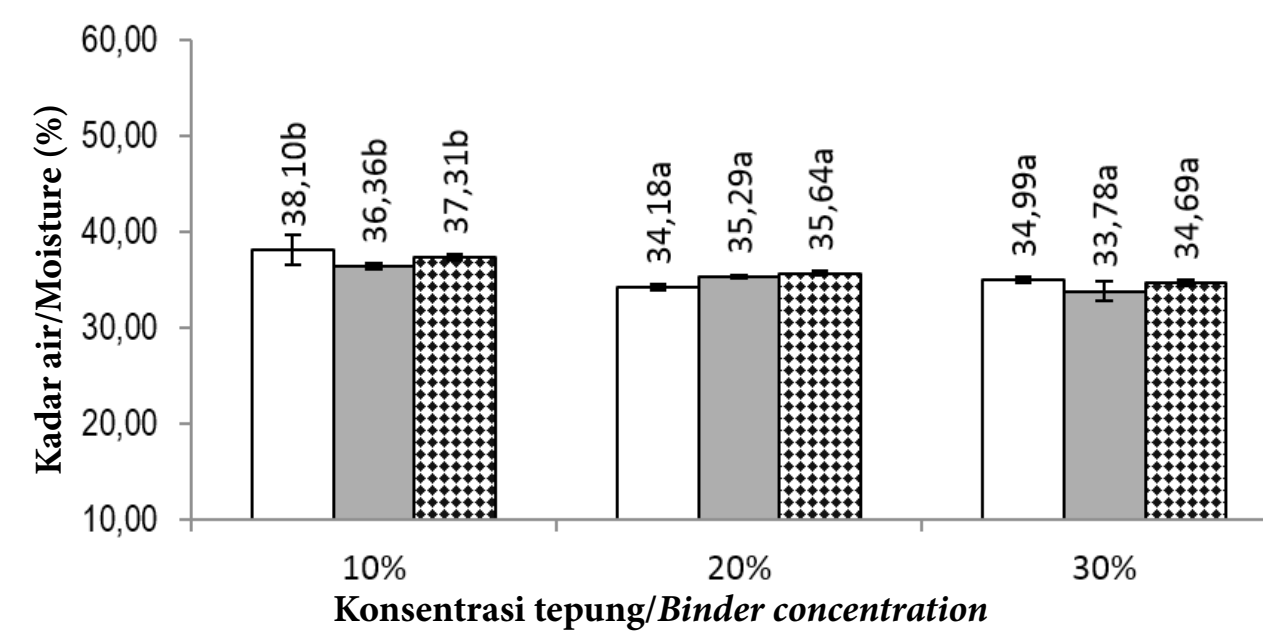

Gambar 3 Kadar air nugget ikan asin berdasar jenis dan konsentrasi binder. $\square$ : maizena; : tapioka; $\square$ :terigu.

(Figure 3 Moisture content of salted fish nugget with various types and concentration of binder flour. $\square$ : cornstarch; $\square$ : tapioca; $\square$ : wheat.) 
penembahan tepung bahan pengikat yang digunakan, hal tersebut sejalan dengan nilai tekstur nugget ikan asin yang lebih empuk (nilai tekstur lebih kecil) pada penambahan tepung $10 \%$ dari pada yang ditambah tepung $20 \%$ dan 30\% (Gambar 2), hal tersebut dapat menjelaskan bahwa kadar air berpengaruh pada tekstur nugget, nugget dengan kadar air lebih tinggi bertekstur lebih empuk dan sebaliknya.

Kadar air pada nugget apabila dihubungkan dengan formula yang digunakan (Tabel 1) bersifat tetap, maka perbedaan kadar air pada nugget ikan asin berhubungan dengan proporsi air terhadap jumlah tepung yang digunakan. Hermansyah (2010) melaporkan bahwa semakin banyak tepung yang ditambahkan maka semakin rendah kadar air nugget. Minyak akan menerima panas selama proses penggorengan, air yang ada dalam nugget akan menguap. Minyak akan masuk pada pori-pori atau ruang kosong yang tadinya terisi oleh air, meskipun demikian kadar air nugget ikan asin masih sesuai persyaratan mutu dan keamanan pangan yaitu maksimum 60\% (BSN 2013).

Kadar air nugget dipengaruhi oleh konsentrasi bahan pengikat yang digunakan. Penambahan tepung bahan pengikat 20 dan $30 \%$ menghasilkan kadar air yang lebih rendah pada nugget daripada penambahan tepung bahan pengikat $10 \%$, apabila kadar air pada nugget tersebut (Gambar 3) dihubungkan dengan tekstur nugget (Gambar 2) maka dapat disimpulkan bahwa tekstur nugget berhubungan dengan kandungan airnya. Nugget yang bertekstur lebih empuk mempunyai kadar air lebih tinggi dari pada nugget yang bertekstur lebih keras.

\section{Organoleptik Hedonik dan Skoring Nugget}

Uji organoleptik hedonik pada dasarnya merupakan suatu uji yang panelisnya dapat mengemukakan respon berupa suka atau tidak suka terhadap sifat bahan yang diuji, Analisis skala hedonik ditransformasikan ke skala numerik kedalam angka menurut tingkat kesukaan. Uji hedonik untuk produk nugget ikan asin meliputi karakteristik produk berdasarkan rasa asin, aroma ikan asin dan tekstur nugget.

Meilgaard et al. (1999) menyatakan bahwa uji hedonik sifatnya personal dan dipengaruhi oleh kultur atau budaya makan, sehingga biasa digunakan untuk uji pasar suatu produk. Hasil uji lanjut Tukey menunjukkan bahwa perbedaan jenis tepung dan interaksi antara konsentrasi dan jenis tepung berpengaruh nyata terhadap tingkat kesukaan (hedonik) rasa asin, aroma ikan asin, tekstur dan penerimaan secara keseluruhan terhadap nugget ikan asin $(\mathrm{p}<0,05)$, tetapi perbedaan konsentrasi tepung tidak berpengaruh nyata terhadap tingkat kesukaan (hedonik) rasa

Tabel 3 Hasil uji hedonik nugget ikan asin berdasar jenis dan konsentrasi binder (Table 3 Hedonic analysis of salted fish nuggets by type and concentration of binder)

\begin{tabular}{|c|c|c|c|c|}
\hline \multirow{2}{*}{$\begin{array}{c}\text { Type and Concentration of } \\
\text { binders }\end{array}$} & \multicolumn{4}{|c|}{ Organoleptic hedonic } \\
\hline & Salty taste & $\begin{array}{l}\text { Scent of salted } \\
\text { fish }\end{array}$ & Texture & $\begin{array}{c}\text { Entirety } \\
\text { acceptance }\end{array}$ \\
\hline Cornstarch $10 \%\left(M_{10}\right)$ & $3.04 \pm 0.00^{\mathrm{a}}$ & $3.77 \pm 0.04^{\mathrm{a}}$ & $3.88 \pm 0.07^{\mathrm{a}}$ & $4.71 \pm 0.07^{\mathrm{ab}}$ \\
\hline Cornstarch $20 \%\left(M_{20}\right)$ & $3.33 \pm 0.11^{b}$ & $3.95 \pm 0.04^{\mathrm{ab}}$ & $4.08 \pm 0.15^{\mathrm{ab}}$ & $4.60 \pm 0.00^{\mathrm{ab}}$ \\
\hline Cornstarch $30 \%\left(M_{30}\right)$ & $3.13 \pm 0.00^{\mathrm{a}}$ & $3.97 \pm 0.04^{\mathrm{ab}}$ & $3.97 \pm 0.15^{\mathrm{a}}$ & $4.79 \pm 0.10^{\mathrm{ab}}$ \\
\hline Tapioca $10 \%\left(T_{10}\right)$ & $3.26 \pm 0.11^{\mathrm{ab}}$ & $3.75 \pm 0.15^{\mathrm{a}}$ & $4.10 \pm 0.08^{\mathrm{ab}}$ & $4.57 \pm 0.19^{\mathrm{a}}$ \\
\hline Tapioca $20 \%\left(T_{20}\right)$ & $3.86 \pm 0.00^{\mathrm{bc}}$ & $3.84 \pm 0.19^{\mathrm{ab}}$ & $4.22 \pm 0.00^{3 \mathrm{~b}}$ & $4.75 \pm 0.04^{\mathrm{ab}}$ \\
\hline Tapioca $30 \%\left(T_{30}\right)$ & $4.13 \pm 0,11^{\mathrm{c}}$ & $4.08 \pm 0.07^{b}$ & $4.51 \pm 0.15^{\mathrm{c}}$ & $4.93 \pm 0.00^{c}$ \\
\hline Wheat flour $10 \%\left(g_{10}\right)$ & $3.42 \pm 0.03^{\mathrm{b}}$ & $3.88 \pm 0.15 \mathrm{a}^{\mathrm{b}}$ & $3.90 \pm 0.08^{\mathrm{a}}$ & $4.39 \pm 0.23^{\mathrm{a}}$ \\
\hline Wheat flour $20 \%\left(g_{20}\right)$ & $3.26 \pm 0.23^{\mathrm{ab}}$ & $4.08 \pm 0.19^{\mathrm{b}}$ & $3.98 \pm 0.11^{\mathrm{a}}$ & $4.82 \pm 0.03^{\mathrm{ab}}$ \\
\hline Wheat flour $30 \%\left(g_{30}\right)$ & $3.35 \pm 0.19^{\mathrm{b}}$ & $3.72 \pm 0.11^{\mathrm{a}}$ & $3.86 \pm 0.03^{\mathrm{a}}$ & $4.77 \pm 0.07^{\mathrm{ab}}$ \\
\hline
\end{tabular}


asin, aroma ikan asin, tekstur dan penerimaan secara keseluruhan nugget ikan asin ( $p>0,05)$. Hasil uji lanjut Tukey dapat dilihat pada Tabel 3.

Tabel 3 menunjukkan bahwa penggunaan tepung tapioka 30\% dalam pembuatan nugget ikan asin merupakan nugget yang paling disukai panelis dari segi rasa asin dan tekstur nugget $(\mathrm{p}<0,05)$. Berdasarkan hedonik aroma ikan asin, penggunaan tapioka 30\% termasuk nugget yang lebih disukai dibandingkan penggunaan tepung maizena $10 \%$, tapioka $10 \%$, dan terigu $30 \%$, namun pada beberapa perlakuan mempunyai nilai yang sama dalam hal tingkat kesukaan dengan nugget yang menggunakan terigu maupun maizena $(\mathrm{p}<0,05)$. Penerimaan secara keseluruhan terhadap nugget ikan asin yang paling tinggi juga terjadi pada nugget yang menggunakan tepung tapioka 30\% dibandingkan dengan jenis tepung dan konsentrasi yang lain $(\mathrm{p}<0,05)$. Hasil tersebut menunjukkan ada beberapa pilihan produk nugget yang mempunyai tingkat kesukaan sama dengan nugget yang menggunakan tapioka 30\%, di antaranya adalah yang menggunakan tapioka $20 \%$.

Nugget yang dinilai memiliki tingkat kesukaan tinggi diintegrasikan/ digabungkan antara perlakuannya maka didapatkan nugget yang paling disukai adalah nugget ikan asin yang menggunakan tepung tapioka $30 \%$. Hal lain yang bisa menunjang pemilihan penggunaan tepung tapioka $30 \%$ pada pembuatan nugget ikan asin berserat pangan adalah nilai ekonomi, harga tepung tapioka lebih murah daripada tepung maizena dan tepung terigu, selain itu tepung tapioka merupakan produk dalam negeri dan mudah ditemukan dipasar.

Nilai hedonik nugget apabila dihubungkan dengan nilai tekstur yang diukur dengan penetrometer (Gambar 2) Penggunaan tapioka 30\% menghasilkan tekstur yang lebih keras daripada tapioka $10 \%$ dan 20\%, maka dapat dikatakan bahwa panelis lebih menyukai nugget ikan asin yang bertekstur sedikit lebih keras atau kenyal.

Pengaruh penggunaan jenis tepung dan konsentrasi tepung terhadap intensitas sifat organoleptik nugget (organoleptik skoring) berupa intensitas rasa asin, aroma ikan asin, dan tekstur dapat dilihat pada Tabel 4. Intensitas sifat organoleptik nugget dihubungkan dengan nugget yang paling disukai, maka nugget yang menggunakan tapioka $30 \%$ mempunyai karakteristik organoleptik rasa asin agak terasa (skor 3,68 ), aroma ikan asin terasa (skor 3,50), dan tekstur agak empuk (skor 3,33). Rasa asin dan aroma ikan asin cenderung menurun

Tabel 4 Hasil analisis skoring organoleptik nugget ikan asin

(Table 4 Organoleptic analysis scores of salted fish nuggets)

\begin{tabular}{|c|c|c|c|}
\hline \multirow{2}{*}{ Type and Concentration of binders } & \multicolumn{3}{|c|}{ Pengujian organoleptik/Organoleptic scoring } \\
\hline & Rasa asin/Salty taste & Aroma/Aroma & Tekstur/Texture \\
\hline Tepung maizena/Cornstarch $10 \%\left(m_{10}\right)$ & $4.86 \pm 0.00$ & $4.51 \pm 0.15$ & $3.46 \pm 0.00$ \\
\hline Tepung maizena/Cornstarch $20 \%\left(m_{20}\right)$ & $4.30 \pm 0.04$ & $3.77 \pm 0.04$ & $3.30 \pm 0.04$ \\
\hline Tepung maizena/Cornstarch $30 \%\left(m_{30}\right)$ & $4.01 \pm 0.00$ & $3.57 \pm 0.04$ & $3.67 \pm 0.00$ \\
\hline Tepung tapioka/Tapioca $10 \%\left(t_{10}\right)$ & $4.40 \pm 0.00$ & $3.90 \pm 0.13$ & $3.02 \pm 0.38$ \\
\hline Tepung tapioka/Tapioca $20 \%\left(t_{20}\right)$ & $4.12 \pm 0.11$ & $3.37 \pm 0.15$ & $3.08 \pm 0.04$ \\
\hline Tepung tapioka/Tapioca 30\% $\left(t_{30}\right)$ & $3.68 \pm 0.07$ & $3.50 \pm 0.04$ & $3.33 \pm 0.23$ \\
\hline Tepung terigu/Wheat flour $10 \%\left(g_{10}\right)$ & $4.24 \pm 0.07$ & $3.48 \pm 0.10$ & $2.90 \pm 0.08$ \\
\hline Tepung terigu/Wheat flour $20 \%\left(g_{20}\right)$ & $3.55 \pm 0.15$ & $3.13 \pm 0.11$ & $3.08 \pm 0.27$ \\
\hline Tepung terigu/Wheat flour $30 \%\left(g_{30}\right)$ & $3.20 \pm 0.00$ & $3.01 \pm 0.14$ & $3.15 \pm 0.04$ \\
\hline \multirow[t]{2}{*}{ Keterangan : - Skor nilai : } & \multicolumn{3}{|c|}{$\begin{array}{ll} & 1=\text { Sangat tidak asin dan } 7=\text { Amat sangat asin } \\
\text { in } 1 & =\text { Sangat tidak terasa dan } 7=\text { Amat sangat ter }\end{array}$} \\
\hline & \multicolumn{3}{|c|}{$1=$ Sangat tidak empuk dan 7=Amat sangat empuk } \\
\hline
\end{tabular}


Tabel 5 Komposisi gizi nugget ikan asin pada perlakuan terbaik

(Table 5 Nutritional composition of the best treatment salted fish)

\begin{tabular}{lcc}
\hline Proksimat/ Proximate analysis & $\begin{array}{c}\text { Nugget penambahan tepung tapioka 30\%/ } \\
\text { Nuggets with the addition of tapioca flour 30\% }\end{array}$ & BSN (2013) \\
\hline Kadar air/Moisture (\%) & 27.48 & Max. 60 \\
Kadar protei/Protein content (\%) & 6.88 & Min. 5.0 \\
Kadar lemak/Lipids content (\%) & 5.84 & Max. 15 \\
Kadar abu/Ash content (\%) & 2.31 & Max. 2.5 \\
Carbohydrate content (\%) & 57.49 & - \\
Dietary fiber total (\%) & 9.30 & - \\
\hline
\end{tabular}

seiring dengan meningkatnya jumlah tepung yang digunakan, sedangkan tekstur nugget cenderung meningkat seiring jumlah tepung yang digunakan.

\section{Penentuan Perlakuan Terpilih}

Rendemen yang lebih tinggi secara ekonomi lebih menguntungkan. Berdasarkan karakteristik fisik berupa rendemen yang lebih tinggi terdapat pada perlakuan konsentrasi tepung $20 \%$ dan $30 \%$ di setiap jenis tepung yang digunakan. Karakteristik fisik tekstur diperoleh tekstur nugget ikan asin yang ditambah tepung 20\% dan 30\% lebih keras daripada yang ditambah tepung $10 \%$, namun secara organoleptik hedonik penambahan tepung 30\% lebih disukai

Jenis tepung bahan pengikat yang digunakan tidak memmengaruhi karakteristik nugget di antaranya rendemen, tekstur, dan kadar air, sehingga ketiga jenis tepung bisa digunakan sebagai bahan pengikat nugget ikan asin. Jenis-jenis tepung yang digunakan tersebut mempunyai harga yang berbeda yang paling mahal adalah terigu, maizena dan tapioka. Nugget ikan asin yang ditambah $30 \%$ tepung bahan pengikat lebih keras dan lebih disukai panelis daripada yang ditambah tepung bahan pengikat $10 \%$ dan $20 \%$, serta pertimbangan ekonomi harga tepung tapioka lebih murah, maka nugget yang terpilih adalah nugget yang menggunakan tepung tapioka $30 \%$.

Nugget dengan perlakuan bahan pengikat tapioka $30 \%$ mempunyai karakteristik organoleptik rasa asin agak terasa, aroma ikan asin terasa, dan tekstur agak empuk, apabila parameter nugget dibandingkan dengan standar SNI, maka nugget terpilih yakni yang menggunakan bahan pengikat tepung tapioka $30 \%$ (Tabel 5) sudah memenuhi dan memili keunggulan kandungan serat pangan yang mencapai 9,30\%.

\section{KESIMPULAN}

Penggunaan jenis bahan pengikat (binder) berupa tepung tapioka dengan konsentrasi $30 \%$ dari berat ikan dan ampas tahu (1:1), menghasilkan nugget ikan asin berserat pangan, berdasarkan karakteristik fisik dan organoleptik, dengan rendemen mencapai $68,25 \%$. Nugget ikan asin terpilih memiliki karakteristik tekstur 14,30 Newton, secara organoleptik agak empuk, kadar air 27,48\%, kadar protein 6,88\%, kadar lemak 5,84\%, kadar abu $2,31 \%$, serat pangan $9,30 \%$, dengan karakteristik organoleptik agak berrasa dan beraroma ikan asin, dan secara keseluruhan disukai panelis.

\section{UCAPAN TERIMA KASIH}

Terima kasih ditujukan kepada Direktorat Penelitian dan Pengabdian kepada Masyarakat, Direktorat Jenderal Pendidikan Tinggi, Kementerian Pendidikan dan Kebudayaan, sesuai dengan Surat Perjanjian Penugasan Program Pengabdian kepada Masyarakat Nomor : 031/SP2H/PPM/DIT. LITABMAS/II/2015 yang telah memberikan bantuan dana penelitian.

\section{DAFTAR PUSTAKA}

Ali M. 2012. Shelf-life determination of brined golden mullet Liza aurata during vacuum refrigerated storage using some quality aspects. Acta Science Policy, Technology, Aliment. 11(1): 37-43.

Anggraeni DA, Widjanarko SB, NingtyasDW. 
2014. Proporsi tepung porang (Amorphophallus muelleri Blume): Tepung maizena terhadap karakteristik sosis ayam. Jurnal Pangan dan Agroindustri. 2(3): 214-223.

[AOAC] Association of Official Analytical Chemyst. 2005. Official Method of Analysis of The Association of Official Analytical of Chemist. Arlington, Virginia (USA): Published by The Association of Official Analytical Chemist. Inc.

Astawan M, Wresdiyati T, Hartanta AB. 2005. Pemanfaatan Rumput Laut sebagai Sumber Serat Pangan untuk Menurunkan Kolesterol Darah Tikus. HAYATI Journal of Biosciences. 12(1) : 23-27.

Aristawati R, Atmaka W, Muhamad DRA. 2013. Substitusi tepung tapioka (Manihot esculenta) dalam pembuatan takoyaki. Jurnal Teknosains. 2(1): 56-65.

[BSN] Badan Standarisasi Nasional. 1992. Standar Ikan Asin Kering : SNI 01-21211992. Jakarta (ID): Badan Standarisasi Nasional.

[BSN] Badan Standarisasi Nasional. 2013. Standar Nugget Ikan : SNI 7758:2013. Jakarta (ID): Badan Standardisasi Nasional Indonesia.

Barat JM, Rodríguez-Barona S, Andrés A, Fito P. 2002. Influence ofincreasing brine concentration in the cod-salting process. Journal of Food Science. 67 (5):1922-1925.

Barat JM, Rodriguez-BaronaS, Andrés A, FitoP. 2003. Cod salting manufacturing analysis. Food Research International. 36(5) : 447-45.

Barat JM, Rodrıguez-Barona S, Andrés A, Visquert M. 2004. Mass transfer analysis during the cod desalting process. Food Research International. 37(3): 203-208.

Belitz HD, Grosch D, Schieberle P. 2009. Food Chemistry, 4th Revised and Extended. Berlin Heidelberg: Springer-Verlag.

Chandalia M, Garg A, Lutjohann D, Bergamann KV, Grundy SM, Brinkley LJ. 2006. Neneficial effects of high dietary fiber intake patients with type 2 diabetes mellitus. The New England Journal of Medicine. 342: 1392-1398.

Desmelati, Hayati R. 2008. Optimasi berbagai tepung kanji pada nugget Ikan Patin terhadap karakteristik sensori dengan metode permukaan Respon. Jurnal Floratek. 3: 35 - 49.

Estiasih T, Trowulan E, Rukmi WD. 2017. Fortifikasi minyak hasil samping pengalengan lemuru pada bakso sapi dan nugget ayam. Jurnal Pengolahan Hasil Perikanan Indonesia. 20(1): 164-178.

Fairudz A, Nisa K. 2015. Pengaruh serat pangan terhadap kadar kolesterol penderita overweight. Majority. 4(8): 121-126.

Gilbert PA, Heiser G. 2005. Salt and health: the CASH andBPA perspective. British nutrition foundation. Nutrition Bulletin. 30: 62-69

Handayani R, Aminah S. 2011. Variasi subtitusi rumput laut terhadap kadar serat dan mutu organoleptik cake rumput laut (Eucheuma cottonii). Jurnal Pangan dan Gizi. 2(3): 67-74.

He FJ, MacGregor GA. 2008. A comprehensive review on salt and health and current experience of worldwide salt reduction programs. Journal of Human Hypertension. 1-22.

Hermansyah R. 2010. Pembuatan nugget udang rebon dengan bahan pengikat jagung dan tepung beras [Skripsi]. Padang (ID): Universitas Andalas.

Jenkins DJA, Kendall CWC, Augustin LSA, Franceschi S, Hamidi M, Marchie A, Jenkins AL, Axelsen M. 2002. Glycemic index: overview of implications in health and disease. American Journal Clinical Nutrition. 76(1): 266S-273S.

Kusharto CM. 2006. Serat makan dan peranannya bagi kesehatan. Jurnal Gizi dan Pangan. 1(2): 45-54

Kusumaningrum M, Kusrahayu, Mulyani S. 2013. Pengaruh berbagai filler terhadap kadar air, rendemen dan sifat organoleptik chicken nugget. Animal Agriculture Journal. 2(1): 370 - 376.

Laksono VP, Bintoro, Mulyani S. 2012. Daya ikat air, kadar air dan protein nugget ayam yang disubsitusi dengan Jamur Tiram Putih (Pleurotus ostreatus).Animal Agriculture Journal. 1(1): 685 -696.

Lutfi AA. 2011. Pengaruh perbandingan tepung terigu dan tepung tapioka dengan 
proporsi yang berbeda terhadap kualitas nugget Ikan Pari (Himantura sp.) selama proses penyimpanan pingin [Skripsi]. Malang (ID): Universitas Brawijaya.

Marsono Y. 2008. Prospek Makanan Fungsional. Jurnal Teknologi Pangan dan Gizi. 7(1) : 19-27.

Meilgaard MC, Civille GV, Carr BT. 1999. Sensory Evaluation Techniques. Third Edition. Boca Raton: CRC Press.

Muklas. 2010. Mempelajari pengendalian mutu (Quality Control) pengolahan tepung terigu di PT. Pundi Kencana Flour Mills Cilegon [Skripsi]. Surakarta (ID): Universitas Sebelas Maret.

Nguyen MV, Jonsson A, Gudjonsdottir M, Arason S. 2010. Drying kinetics of salted cod in a heat pump dryer as influenced by different salting procedures. Asian Journal Food and Agro-Industry. 4(1): 2230.

Nurhalimah L, Fathonah S, Nurani D. 2012. K andungan gizi dan daya terima makanan tambahan ibu hamil trimester pertama. Food Science and Culinary Education Journal. 1(1): 1-12.

Redondo-Cuenca M, Villanueva-Suarez J, Mateos-Aparicio I. 2008. Soybean seeds and its by-product okara as sources of dietary fibre. Journal Food Chemistry.108: 1099-1105.

Restu. 2012. Pemanfaatan ikan Toman (Channa micropeltes) sebagai bahan nugget. Jurnal Ilmu Hewani Tropika.1(2): 17-38.

Riyanto B, Wilakstanti M. 2006. Cookies berkadar serat tinggi substitusi tepung ampas rumput laut dari pengolahan agar-agar kertas. Buletin Teknologi Hasil Perikanan. 9 (1): 49-60.

Rosyidi D, Widati AS, Prakoso J. 2008. Pengaruh penggunaan rumput laut terhadap kualitas fisik dan organoleptik chicken nugget. Jurnal Ilmu dan Teknologi Hasil Ternak. 3(1): 43-51.

Saniah K, Rahani ZC. 2011. Acceptability and textural quality of Sri Pontian cassava nuggets using Response Surface Methodology. Journal Tropical Agricultural and Food Science. 39(2): 131-139.
Sulistiani. 2004. Pemanfaatan ampas tahu dalam pembuatan pangan tinggi serat dan protein sebagai alternatif bahan baku pangan fungsional. [Skripsi]. Bogor (ID): Institut Pertanian Bogor.

Suprapti L. 2005. Pembuatan Tahu. Yogyakarta (ID): Penerbit Kanisius.

Surawan FED. 2007. Penggunaan tepung terigu, tepung beras, tepung tapioka dan tepung maizena terhadap tekstur dan sifat sensoris fish nugget ikan tuna. Jurnal Sain Peternakan Indonesia. 2(2): 78-84.

Syahruddin H. 2013. Pengaruh penggaraman terhadap protein Ikan Layang (Decapterus rucel). Jurnal Ilmiah Mahasiswa Universitas Surabaya. 2(1): 1-11.

Suwanto. 2006. Pengaruh komposisi tepung tapioka dan daging merah serpih tuna terhadap karakteristik dan tingkat kesukaan fish nugget. [Skripsi]. Padang(ID): Universitas Andalas.

Ünlüsayın $M$, Gümüş B, Erdilal R, Gülyavuz H. 2008. The investigation of extract loss of horse mackerel (Trachurus trachurus L. 1758) with different salting methods. E.U. Journal of Fisheries and Aquatic Sciences. 25(3): 217-220.

Ünlüsayın $M$, Gümüs $B$, Ruhan Erdilal R, Gülyavuz H. 2011. The influence of different salting processes on protein loss of cuttlefish (Sepia officinalis). Ege Journal of Fisheries and Aquatic Sciences.28(3): 71-74.

Widayanti NP, Laksmita AS. 2017. Hubungan tingkat pengetahuan penjual terhadap identifikasi formalin pada ikan asin di pasar tradisional Kota Denpasar tahun 2017. Medicamento. 3(1): 44-47.

Witono JRB, Miryanti YIPA, Yuniarti L. 2013. Studi kinetika dehidrasi osmotik pada Ikan Teri dalam larutan biner dan terner. Bandung (ID): Laporan Penelitian LPPM Universitas Parahiyangan.

Wonggo D. 2010. Penerimaan konsumen terhadap selai rumput laut Kappaphycus alvarezii. Jurnal Perikanan dan Kelautan. 6(1): 51-53.

Yusop SM, Maskat MY, Mustapha WA, Abdullah A. 2009. Properties of coating systems during the initial period of deep-fat frying as affected by flour 
type, temperature and pressure. Sains Malaysiana. 38(2): 177-183.

Zulkarnain J. 2013. Pengaruh perbedaan komposisi tepung tapioka terhadap kualitas bakso Lele [Skripsi]. Padang (ID): Universitas Negeri Padang. 